\title{
Restriction Mediated by pAV2 Affects the Transfer of Plasmids in Acinetobacter calcoaceticus
}

\author{
By EDWARD HINCHLIFFE† AND ALAN VIVIAN* \\ School of Biological Sciences, Thames Polytechnic, London SE18 6PF
}

(Received 18 April 1980; revised 3 June 1980)

The naturally occurring plasmid pAV2 restricts the entry of the P class plasmid RP4 and the W class plasmids R388 and S-a into Acinetobacter calcoaceticus strain EBF65/65 from Escherichia coli. The W class plasmids only transfer from $E$. coli into pAV2- strains. Plasmid RP4 is modified in the presence of pAV2 such that it is no longer restricted on entry into pAV2 recipients of strain EBF65/65.

\section{INTRODUCTION}

Members of the $\mathbf{P}$ incompatibility group of plasmids are the only group of plasmids so far shown to transfer from Escherichia coli to Acinetobacter calcoaceticus strain EBF65/65 (Towner \& Vivian, 1977). The naturally occurring plasmid pAV1, isolated from a hospital strain of Acinetobacter, has been shown to be incompatible with the P group plasmids RP4 and R751 in strain EBF65/65 (Hinchliffe \& Vivian, 1980a). In the preceding paper we reported the existence of a cryptic plasmid, pAV2, present in strain EBF65/65 (Hinchliffe et al., 1980) which is responsible for variation in the fertility of the sex factor pAV1 (Hinchliffe \& Vivian, 1980 b). A possible mechanism whereby pAV2 affects the frequency of pAV1 transfer has been discussed, and it has been suggested that pAV2 determines a restrictionmodification system in its host strain.

In this paper we report on the ability of pAV2 to affect the frequency of RP4 transfer in matings between $E$. coli and $A$. calcoaceticus and also within $A$. calcoaceticus. Experiments to test for transfer to $A$. calcoaceticus of members of the $\mathrm{C}, \mathrm{F}, \mathrm{N}$ and $\mathrm{W}$ incompatibility groups show that the cryptic plasmid pAV2 exerts control over the acceptability of two members of the $\mathrm{W}$ incompatibility group.

\section{METHODS}

Bacterial strains and plasmids. These are listed in Table 1.

Media. These were as described by Towner \& Vivian (1976a). Complete medium was Oxoid nutrient agar. Antibiotics. These were obtained from Sigma and were used at the following final concentrations: chloramphenicol, $40 \mu \mathrm{g} \mathrm{ml}^{-1}$; sulphadiazine, $500 \mu \mathrm{g} \mathrm{ml}^{-1}$; tetracycline hydrochloride, $5 \mu \mathrm{g} \mathrm{ml}^{-1}$.

Millipore mating technique. The method of Towner \& Vivian (1976b) was used for all quantitative crosses.

Replica plate mating. The method described by Hinchliffe \& Vivian (1980a) was used for the preliminary detection of plasmid transfer and for the investigation of the ability of RP4+ transconjugants to accept pAV1.

Stability of plasmids. This was determined as described by Towner \& Vivian (1976a).

$\uparrow$ Present address: Department of Molecular Biology, University of Edinburgh, King's Buildings, Mayfield Road, Edinburgh EH9 3JR. 


\section{Table 1. Bacterial strains and plasmids}

$\begin{array}{lll}\begin{array}{l}\text { Bacterial strain } \\ \text { Acinetobacter calcoaceticus }\end{array} & \text { Relevant characteristics } & \text { Reference/source } \\ \text { C4153 } & \text { met-1 ile-1 (pAV1) } & \text { Hinchliffe } \text { et al. }(1980) \\ \text { C426 } & \begin{array}{l}\text { trp-2 his-1 (pAV2) } \\ \text { trp-2 his-1 }\end{array} & \text { Hinchliffe } \text { et al. }(1980) \\ \text { C4169 } & \text { phe-1 thi-2 (pAV2) } & \text { Hinchliffe } \text { et al. }(1980) \\ \text { C484 } & \text { Hinchliffe } \text { et al. }(1980) \\ \text { C4161 } & & \text { Hinchliffe } \text { et al. }(1980) \\ \text { Escherichia coli } & & \\ \text { J53 } & \text { pro met } & \text { Clowes \& Hayes (1968) } \\ \text { J53-1 } & \text { pro met } \text { nal } & \text { Clowes \& Hayes (1968) }\end{array}$

\begin{tabular}{lcll} 
Plasmid & $\begin{array}{c}\text { Incompatibility } \\
\text { group }\end{array}$ & Resistance markers* & \multicolumn{1}{c}{ Reference/source } \\
RP4 & P & Ap,Km,Tc & Datta et al. $(1971)$ \\
pAV1 & P & Su & Hinchliffe \& Vivian $(1980 a)$ \\
R40a & C & Ap,Km,Su & Datta \& Hedges $(1972 b)$ \\
R57b & C & Ap,Cm,Gm,Su & Datta \& Hedges $(1972 a)$ \\
R1-16 & FII & Ap,Cm,Km,Sm,Su & Meynell \& Cooke $(1969)$ \\
R388 & W & Su,Tp & Datta \& Hedges $(1972 a)$ \\
S-a & W & Cm,Km,Sm,Su & Watanabe et al. $(1968)$ \\
R390 & N & Ap,Cm,Sm,Su,Tc & Coetzee et al. $(1972)$ \\
pAV2 & - & - & Hinchliffe et al. $(1980)$
\end{tabular}

* Ap, ampicillin; $\mathrm{Cm}$, chloramphenicol; $\mathrm{Gm}$, gentamicin; $\mathrm{Km}$, kanamycin; Sm, streptomycin; $\mathrm{Su}$, sulphonamides; Tc, tetracycline; $\mathrm{Tp}$, trimethoprim.

Table 2. Transfer of $P$ and $W$ incompatibility group plasmids between E. coli and A. calcoaceticus EBF65/65

$\begin{array}{llcc}\text { Donor } & \text { Recipient } & \begin{array}{c}\text { Selected plasmid } \\ \text { marker* }\end{array} & \begin{array}{c}\text { Mean frequency } \\ \text { of transfer }\end{array} \\ \text { J53(RP4) } & \text { C484(pAV2) } & \text { Tc } & 5.4 \times 10^{-5} \\ \text { J53(RP4) } & \text { C4161 } & \text { Tc } & 4 \cdot 1 \times 10^{-2} \\ \text { J53(R388) } & \text { C4169 } & \text { Su } & 1.2 \times 10^{-6} \\ \text { J53-1(S-a) } & \text { C4169 } & \text { Su } & 1.8 \times 10^{-7} \\ & * \text { Su, sulphonamides; Tc, tetracycline. } \\ & \dagger \text { R+ transconjugants per recipient. }\end{array}$

\section{RESULTS}

Intergeneric plasmid transfer

Strains of $E$. coli $\mathrm{K} 12$ harbouring the plasmids listed in Table 1 were crossed with $A$. calcoaceticus by the Millipore mating technique; (Table 2). Strain C4161 lacking pAV2 received RP4 at approximately 1000 -fold higher frequency than the isogenic pAV2 strain C484. In addition, the pAV2- strain C4169 received the W plasmids S-a and R388 at a detectable frequency $\left(>1 \times 10^{-7} R^{+}\right.$transconjugants per recipient), whereas the isogenic pAV2 strain C426 did not. Plasmid transfer was not detected (frequency of transfer $<1 \times$ $10^{-8}$ ) for $\mathrm{C}, \mathrm{N}$ or $\mathrm{F}$ incompatibility group plasmids with either recipient.

\section{Transfer of plasmids within A. calcoaceticus}

Crosses were performed between appropriately marked strains carrying combinations of RP4 and pAV2, so that transfer of RP4 in A. calcoaceticus could be tested (Table 3 ). The mating mixtures were plated on media selecting for transfer of tetracycline resistance. Transfer between RP4 donors lacking pAV2 [C4161(RP4)] and pAV2 recipients resulted in a frequency of RP4 transfer 100 times lower than for crosses to the isogenic recipient lacking pAV2; whereas crosses involving RP4 donors possessing pAV2 differed only slightly (10- 
Table 3. Transfer of plasmids within A. calcoaceticus EBF65/65

\begin{tabular}{|c|c|c|c|}
\hline Donor & Recipient & $\begin{array}{l}\text { Selected plasmid } \\
\text { marker* }\end{array}$ & $\begin{array}{c}\text { Mean frequency } \\
\text { of transfer } \dagger\end{array}$ \\
\hline C4161(RP4) & C426(pAV2) & $\mathrm{Tc}$ & $2.0 \times 10^{-5}$ \\
\hline C4161(RP4) & C4169 & $\mathrm{Tc}$ & $6.8 \times 10^{-3}$ \\
\hline C484(RP4)(pAV2) & $\mathrm{C} 426(\mathrm{pAV} 2)$ & $\mathrm{Tc}$ & $1.0 \times 10^{-3}$ \\
\hline C484(RP4)(pAV2) & C4169 & $\mathrm{Tc}$ & $1.2 \times 10^{-2}$ \\
\hline C4161(S-a) & C426(pAV2) & $\mathrm{Cm}$ & $<1.0 \times 10^{-8}$ \\
\hline C4161(S-a) & C4169 & $\mathrm{Cm}$ & $2.9 \times 10^{-6}$ \\
\hline C4161(R388) & C426(pAV2) & $\mathrm{Su}$ & $<1.0 \times 10^{-8}$ \\
\hline C4161(R388) & C4169 & $\mathrm{Su}$ & $5.3 \times 10^{-6}$ \\
\hline
\end{tabular}

fold) in their frequency of RP4 transfer to pAV2 and pAV2- recipients. This implies that pAV2 can both restrict and modify RP4 DNA, such that it is able to affect the acceptability of RP4 DNA.

The W group plasmids S-a and R388 showed a low, but detectable, frequency of transfer within $A$. calcoaceticus ( $>1 \times 10^{-6} \mathrm{R}^{+}$transconjugants per recipient), but were only able to transfer to recipients lacking the plasmid pAV2 (Table 3 ). It is apparent from these results that pAV2 is also able to affect the acceptability of W plasmid DNA.

\section{Stability of $W$ plasmids in $A$. calcoaceticus}

Strain C4169(S-a) was tested for the retention of S-a on the basis of resistance to sulphonamides; 826 in 836 colonies tested retained resistance to sulphonamides. When strain C4161(R388) was tested, 915 in 917 colonies tested retained resistance to sulphonamides.

\section{RP4 transconjugants show variable frequencies of transfer}

A sample of strain C484(RP4) transconjugants selected from the cross between $E$. coli J53(RP4) and C484 were tested by replica plate mating for their ability to receive pAV1 from the a-type donor $\mathrm{C} 4153$. The mating plates were replicated to appropriately supplemented minimal medium, selecting for pAV1 transfer. Two in 88 RP4 transconjugants sampled were able to accept pAV1 at a high frequency, indicative of pAV1 transfer into a recipient lacking pAV2 (Hinchliffe et al., 1980). The remaining 86 RP4 transconjugants received pAV1 at a low frequency. When one of the two RP4 transconjugants with high frequency recipient activity of pAV1 was mated with C426(pAV2) by the Millipore technique, there was an approximately 100 -fold reduction in the frequency of RP4 transfer, as compared with an RP4 transconjugant showing low frequency recipient activity of pAV1 when mated under the same conditions. This implies that it is possible to derive RP4 transconjugants in $A$. calcoaceticus which show two types of fertility when crossed with C426(pAV2). Those transconjugants showing low frequency RP4 transfer can be described as $\mathrm{RP}^{+}{ }^{+} \mathrm{pAV} 2^{-}$, whereas those showing high frequency transfer are $\mathrm{RP}^{+}{ }^{+} \mathrm{pAV} 2^{+}$.

\section{DISCUSSION}

The object of this investigation was to determine whether plasmids belonging to different incompatibility groups could be transferred from $E$. coli to strains of $A$. calcoaceticus lacking the plasmid pAV2. Towner \& Vivian (1977) showed that only members of the P incompatibility group could be transferred to $A$. calcoaceticus EBF65/65; since this strain harbours the cryptic plasmid pAV2 which affects the host specificity of the sex factor pAV1 (Hinchliffe et al., 1980) it seemed reasonable to test the hypothesis that pAV2 can restrict the transfer or entry of other plasmids into strain EBF65/65. The results presented here indicate that 
pAV2 can indeed restrict the entry of the W plasmids R388 and S-a, since recipients lacking pAV2 accept these plasmids from $E$. coli. It also appears that pAV2 restricts transfer within Acinetobacter, because pAV2 recipients are unable to receive R388 and S-a from pAV2donors. It was not possible to obtain strains which possessed pAV2 and R388 or S-a; one might expect such strains to demonstrate $\mathrm{R}^{+}$transfer to pAV2 recipients in the same way as $\mathrm{R}^{+}$transfer in a pAV2- system. The apparent low frequency of transfer of the $\mathrm{W}$ group plasmids in strain EBF65/65 cannot be explained in terms of their instability; although R388 is slightly more stable than S-a both plasmids show little instability. The $\mathrm{C}, \mathrm{N}$ and $\mathrm{F}$ plasmids tested did not transfer to any of the strains of EBF65/65 tested. This may imply that either these strains possess a second, possibly chromosomally determined, restrictionmodification system, or alternatively these plasmids are intrinsically unable to transfer to A. calcoaceticus; the latter explanation may in part be the reason why R388 and S-a transfer at a low frequency within $A$. calcoaceticus.

The P class plasmid RP4 (Datta et al., 1971) is affected by the presence of pAV2 in the mating strains, such that the frequency of $R^{+}$transfer is reduced by the presence of pAV2 in the recipient. This would indicate that RP4 is restricted by pAV2; however, RP4 donors possessing pAV2 do not show any appreciable reduction in the frequency of $R^{+}$transfer, implying modification of RP4 by pAV2. The effect of pAV2 on RP4 is analogous to that shown for pAV1 (Hinchliffe et al., 1980), since the host specificity of each is affected by pAV2. The presence or absence of pAV2 in strains of EBF65/65 has no bearing on the incompatibility determinations for pAV1 since all the strains were pAV2+ (Hinchliffe \& Vivian, 1980a). Similar results were also obtained by Hinchliffe \& Vivian (1980 $b$ ) in strains which differed with respect to pAV2. Incompatibility remained the same when similar crosses were performed in strains that were all pAV2- (E. Hinchliffe \& A. Vivian, unpublished results).

RP4 has been described by various authors as a wide host range plasmid (Datta et al., 1971; Datta \& Hedges, 1972 c; Olsen \& Shipley, 1973). Barth \& Grinter (1977) showed that RP4 has a limited number of restriction sites which would be an evolutionary advantage to a promiscuous plasmid. The W plasmid R388, on the other hand, which is not renowned for its promiscuity, possesses a number of sites susceptible to restriction (Ward \& Grinsted, 1978). Thus, the efficiency of pAV2-mediated restriction against RP4, R388, S-a and pAV1 (Hinchliffe et al., 1980) may be dependent on the number of restriction target sites carried by the infecting plasmid DNA (Arber, 1974). The results presented here perhaps provide an insight into the way in which plasmid host range is affected in nature.

It is a pleasure to record our thanks to Dr M. E. Nugent, Dr P. H. Williams and J. Errington for many helpful discussions during the course of this work.

\section{REFERENCES}

Arber, W. (1974). DNA modification and restriction. Progress in Nucleic Acid Research and Molecular Biology 14, 1-37.

BARTH, P. T. \& GRINTER, N. J. (1977). Map of plasmid RP4 derived by insertion of transposon C. Journal of Molecular Biology 113, 455-474.

Clowes, R. C. \& HAYES, W. (1968). Experiments in Microbial Genetics. Oxford \& Edinburgh: Blackwell Scientific Publications.

Coetzee, J. N., DatTa, N. \& Hedges, R. W. (1972). $\mathrm{R}$ factors from Proteus rettgeri. Journal of General Microbiology 72, 543-552.

Datta, N. \& Hedges, R. W. (1972a). Trimethoprim resistance conferred by $\mathrm{W}$ plasmids in Entero- bacteriaceae. Journal of General Microbiology 72, 349-356.

DatTa, N. \& Hedges, R. W. (1972b). R factors identified in Paris, some conferring gentamycin resistance, constitute a new compatibility group. Annales de l'Institut Pasteur 123, 849-852.

DatTA, N. \& Hedges, R. W. $(1972 c)$. Host ranges of $\mathrm{R}$ factors. Journal of General Microbiology $\mathbf{7 0}$, $453-460$.

Datta, N., Hedges, R. W., Shaw, E. J., Sykes, R. B. \& Richmond, M. H. (1971). Properties of an $\mathrm{R}$ factor from Pseudomonas aeruginosa. Journal of Bacteriology 108, 1244-1249. 
Hinchliffe, E. \& Vivian, A. (1980a). Naturally occurring plasmids in Acinetobacter calcoaceticus: a $\mathbf{P}$ class $\mathbf{R}$ factor of restricted host range. Journal of General Microbiology 116, 75-80.

HinCHLIFFe, E. \& ViviaN, A. $(1980 b)$. Gene transfer in Acinetobacter calcoaceticus: fertility variants of the sex factor pAV1. Journal of General Microbiology 119, 117-122.

Hinchliffe, E., Nugent, M. E. \& Vivian, A. (1980). Naturally occurring plasmids in Acinetobacter calcoaceticus: pAV2, a plasmid which influences the fertility of the sex factor pAV1. Journal of General Microbiology 121, 411-418.

Meynell, E. \& Cooke, M. (1969). Repressor-minus and operator-constitutive derepressed mutants of F-like $\mathbf{R}$ factors: their effect on chromosomal transfer by HfrC. Genetical Research 14, 309-313.

Olsen, R. H. \& SHIPLEY, P. (1973). Host ranges and properties of the Pseudomonas aeruginosa $\mathbf{R}$ factor R1822. Journal of Bacteriology 113, 772-780.
TOWNER, K. J. \& VIVIAN, A. (1976a). RP4-mediated conjugation in Acinetobacter calcoaceticus. Journal of General Microbiology 93, 355-360.

Towner, K. J. \& Vivian, A. (1976b). RP4 fertility variants in Acinetobacter calcoaceticus. Genetical Research 28, 301-306.

TOWNER, K. J. \& Vivian, A. (1977). Plasmids capable of transfer and chromosome mobilization in Acinetobacter calcoaceticus. Journal of General Microbiology 101, 167-171.

WARD, J. M. \& GRINSTED, J. (1978). Mapping of functions in the R-plasmid R388 by examination of deletion mutants generated in vitro. Gene 3 , 87-95.

Watanabe, T., Furuse, C. \& Sakaizumi, S. (1968). Transduction of various $R$ factors by phage $P 1$ in Escherichia coli and by phage P22 in Salmonella typhimurium. Journal of Bacteriology 96, 17911795. 